\title{
Innovation and certification as the basis for the development of energy-efficient construction
}

\author{
Natalya Trukhina ${ }^{1}$, Valery Barinov ${ }^{1}$, Yana Andryunina ${ }^{1,}{ }^{*}$ Andrey Panenkov ${ }^{1}$ and Nikolay \\ Voytolovskiy $^{2}$ \\ ${ }^{1}$ Voronezh State Technical University, Moscow Avenue, 14, Voronezh, 394026, Russia \\ ${ }^{2}$ Sankt-Petersburg State Economic University, 21, Sadovaya street, St. Petersburg, 191023, Russia
}

\begin{abstract}
Within the framework of the concept of sustainable development, issues of energy efficiency, environmental safety, minimization of anthropogenic impact on the environment are of particular relevance. In construction, these theses are projected onto the segment of energy-efficient, "green" construction. Nowadays, the development of energy-efficient construction in Russia is progressing at a slow pace, and this is primarily due to the lack of an integrated energy management system, environmental certification of construction products, and institutional features of the real estate market. The authors systematized the methods of improving energy efficiency and greening of construction regarding the types of real estate, analyzed the main global and Russian environmental certification systems in construction, identified the features, advantages and disadvantages of each system, substantiated the need to ensure the generally accepted Russian certification system. The problem of enhancing energy-efficient construction is also interconnected with the need to increase the level of innovation in construction, which is substantiated by the authors in the paper. The authors substantiated the need to change the criteria for monitoring investment projects, taking into account the optimization of energy efficiency and environmental performance of real estate.
\end{abstract}

\section{Introduction}

A key aspect in the projection of creating physical capital for sustainable development is ensuring the quality of construction products, and, according to the opinion of leading scientists [1], this is the quality of both final and intermediate products. It should be noted that the life cycle of construction products is long enough, which leads to the conclusion that it is also necessary to take into account the quality of operation of the constructed real estate. Moreover, in our opinion, because of its duration, it is the operational phase of the life cycle that affects the well-being of future generations. Therefore, today the problem of energy intensity and energy efficiency, environmental friendliness of construction products is acutely posed.

\footnotetext{
*Corresponding author: jarogacheva@mail.ru
} 
The focus of modern Russian construction on the problem of improving energy efficiency and product quality often does not take into account the provision of safety and favorable healthy living conditions. Thus, the creation of energy-efficient residential buildings without taking into account the necessary supply ventilation has a negative impact on human health. WHO data show that $35 \%$ of all erected buildings are subject to pollution by various substances [2]. Therefore, in our opinion, the following should be attributed to the criteria of "green" construction: rational use of resources, minimizing the impact on the environment, ensuring safe healthy conditions for humans. It is the combination of the three criteria that gives the project the right to be called a "green" construction project.

All researchers of this problem point out another property of "green" construction objects - their innovation [3,4], implementation of the principle of innovation [5] makes it necessary to implement a whole complex of interrelated changes and transformations in the institutional, economic, and technical spheres not only of construction enterprises but also other industries and complexes.

Changes initiated and implemented in the activities of the enterprise in accordance with the trends of self-organization and adaptation to the dynamics of the environment must be planned on the basis of scientific approaches, taking into account the trends of the knowledge economy and the innovative nature of transformations. The above is especially important for the effective innovative development of enterprises of the construction complex in the implementation of investment projects. Institutional and economic changes implemented at the macro level in the pricing system, standard and technical regulation, control of the quality and cost of investment and construction projects often do not lead to increased innovation activities in enterprises. Therefore, it is necessary to improve the methodological framework for implementing such changes to achieve not only an economic but also a technical, innovative effect, improving the quality and functional properties of building products.

\section{Materials and Methods}

The trend of greening concerns not only residential real estate. As a result of the conducted analysis of the use of ecotechnologies in the construction and operation of real estate, a tendency towards the greening of all types of objects was substantiated. At the same time, the classification of real estate can be made for various reasons. In order to detail the results of the study, we have adopted a classification of real estate [6,7], in which the elements of public real estate are most fully revealed.

Table 1.Substantiation of the construction greening process in the projection of types of real estate.

\begin{tabular}{|c|c|c|}
\hline Type of real estate & $\begin{array}{l}\text { Method of greening } \\
\text { construction }\end{array}$ & Examples of "green" buildings \\
\hline \multicolumn{3}{|c|}{ Residential real estate: } \\
\hline - apartment houses & $\begin{array}{l}\text { Certification according to } \\
\text { standards, "green" } \\
\text { construction }\end{array}$ & $\begin{array}{l}\text { "Triumph Park" in St. Petersburg } \\
\text { (BREAM certificates), Passive house in } \\
\text { South Butovo (Moscow) (Passive House } \\
\text { certificate) }\end{array}$ \\
\hline $\begin{array}{l}\text { - single-family } \\
\text { houses }\end{array}$ & $\begin{array}{l}\text { Certification according to } \\
\text { standards, "green" } \\
\text { construction }\end{array}$ & $\begin{array}{l}\text { "Active House", "Western Valley" Naro- } \\
\text { Fominsky District, Moscow } \\
\text { "Volkhonka", Moscow } \\
\text { (EcoVillage Certificates) }\end{array}$ \\
\hline - terraced houses & $\begin{array}{l}\text { Certification according to } \\
\text { standards, "green" } \\
\text { construction }\end{array}$ & RC “Technopark” Skolkovo \\
\hline
\end{tabular}




\begin{tabular}{|l|l|l|}
\hline Commercial real estate: & $\begin{array}{l}\text { Certification according to } \\
\text { standards, Fit-out }\end{array}$ & $\begin{array}{l}\text { Projects "Radumlya", "BelyyRast" and } \\
\text { "South Gate" Outlet Village Belaya } \\
\text { Dacha (BREAM certificates) }\end{array}$ \\
\hline Office & $\begin{array}{l}\text { Certification according to } \\
\text { standards, Fit-out }\end{array}$ & $\begin{array}{l}\text { BC "Marr Plaza", Ducat Place III, } \\
\text { Moscow (BREAM certificates), Siemens } \\
\text { office in Moscow (LEED certificate) }\end{array}$ \\
\hline Industrial property & $\begin{array}{l}\text { Certification according to } \\
\text { standards, "green" } \\
\text { construction }\end{array}$ & $\begin{array}{l}\text { SKF plant in Tver (LEED certificate), } \\
\text { Hamilton Standard-Science, Kimry (LEED } \\
\text { certificate) }\end{array}$ \\
\hline property purpose & $\begin{array}{l}\text { Certification according to } \\
\text { standards, "green" } \\
\text { construction }\end{array}$ & $\begin{array}{l}\text { Central Stadium, Grand Ice Arena, Indoor } \\
\text { Speed Skating Center, Training and } \\
\text { Administration Building of the Russian } \\
\text { International Olympic University (RIOU), } \\
\text { Sochi (BREAM certificates) }\end{array}$ \\
\hline $\begin{array}{l}\text { Recreational } \\
\text { property }\end{array}$ & $\begin{array}{l}\text { Certification according to } \\
\text { standards, "green" } \\
\text { construction, Fit-out }\end{array}$ & $\begin{array}{l}\text { OCC Hotel, Sochi (BREAM certificates), } \\
\text { Russian Seasons Hotel in Sochi (Russian } \\
\text { Standard certification GOST R 54964- } \\
\text { 2012) }\end{array}$ \\
\hline
\end{tabular}

In accordance with the data in the table, the main criterion for classifying an object as a "green" construction object is certification according to one of accepted eco-standards.

Environmental systems that allow assessing the diverse aspects of the building, in contrast to the standards, do not list certain materials or technical solutions, but individually assess each property by a specific list of indicators.

The principle of assessment is the same for each system, and is a point-weight method:

$$
\mathrm{R}=\sum \mathrm{r}_{\mathrm{ij}} \times \mathrm{v}_{\mathrm{ij}}
$$

where $\mathrm{R}$ - total rating of the real estate, $r_{i j}$ - rating by the $\mathrm{j}$-th criterion of the $\mathrm{i}$-th category, $v_{i j}$ - weight of the $j$-th criterion of the $i$-th category of assessment.

Nowadays, Russia has a number of certification systems for "green" buildings, each of which has its own advantages and disadvantages.

\section{Results}

Due to the lack of mandatory focusing on the use of one of the "green" certification systems, we consider it necessary to assess the main listed systems according to the modified SWOT analysis method. The results of the analysis can also be used in the development of the unified all-Russian certification system for "green" construction objects.

Table 2. SWOT analysis of the main systems of "green" certification of real estate objects used in Russia.

\begin{tabular}{|c|l|l|}
\hline Standard & \multicolumn{1}{|c|}{ Advantages / Features } & \multicolumn{1}{c|}{ Disadvantages / Threats } \\
\hline \multirow{3}{*}{$\begin{array}{l}\text { Dominant - minimizing the impact of the } \\
\text { object on the environment }\end{array}$} & $\begin{array}{l}\text { Based on Eurocodes, UK standards and } \\
\text { local norms } \\
\text { Preparation of certified evaluators } \\
\text { Accepts local standards } \\
\text { Allows comparing objects }\end{array}$ & $\begin{array}{l}\text { Strict requirements } \\
\text { Difficult rating system }\end{array}$ \\
\cline { 2 - 3 } & $\begin{array}{l}\text { Feasibility of using alternative energy } \\
\text { Reliability of assessment }\end{array}$ & $\begin{array}{l}\text { Difficulty of adaptation to the Russian } \\
\text { conditions (variety of regional specifics) }\end{array}$ \\
\hline \multirow{2}{*}{$\begin{array}{l}\text { Compatibility with Russian needs } \\
\text { (dominant - energy efficiency) }\end{array}$} & $\begin{array}{l}\text { Based on American standards ASTM, } \\
\text { ASHRAE } \\
\text { Assessment of the territory development } \\
\text { Consideration of regional specifics }\end{array}$ & $\begin{array}{l}\text { Assesment materials are provided by the } \\
\text { customer in English }\end{array}$ \\
\hline
\end{tabular}




\begin{tabular}{|c|c|c|}
\hline & $\begin{array}{l}\text { Accounting for innovation } \\
\text { Universal evaluation processes }\end{array}$ & $\begin{array}{l}\text { Strong binding of architectural solutions } \\
\text { to the functional purpose of the object } \\
\text { Key subject - Designer }\end{array}$ \\
\hline & $\begin{array}{l}\text { The standard is more commercial, } \\
\text { focused on energy and water } \\
\text { consumption } \\
\text { LEED basic level buildings are easy to } \\
\text { compare. } \\
\text { Strict minimum requirements }\end{array}$ & $\begin{array}{l}\text { Difficulty of adaptation to the Russian } \\
\text { NTD system } \\
\text { Possibility of lobbying the interests of the } \\
\text { customer } \\
\text { Danger of greenwashing at the stages of } \\
\text { construction and operation of the facility } \\
\text { LEED implementation is almost } \\
\text { impossible at later stages (after } \\
\text { construction has begun). }\end{array}$ \\
\hline \multirow{2}{*}{ 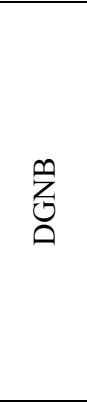 } & $\begin{array}{l}\text { Based on European building codes } \\
\text { Object life cycle assessment } \\
\text { Accounting for technical equipment and } \\
\text { economic efficiency } \\
\text { Flexible and balanced assessment } \\
\text { methodology }\end{array}$ & $\begin{array}{l}\text { There are separate building advantages } \\
\text { Low attention to passive energy saving } \\
\text { methods } \\
\text { No assessment of innovations }\end{array}$ \\
\hline & $\begin{array}{l}\text { Easy to adapt to the Russian NTD system } \\
\text { Comprehensive assessment of the OLC } \\
\text { efficiency } \\
\text { Accounting for the realities of the } \\
\text { Russian Federation }\end{array}$ & $\begin{array}{l}\text { Possibility of lobbying the interests of the } \\
\text { customer } \\
\text { Rising the cost of the project to achieve } \\
\text { energy efficiency }\end{array}$ \\
\hline \multirow{2}{*}{$\underset{2}{\stackrel{1}{O}}$} & $\begin{array}{l}\text { Based on European building codes } \\
\text { Compatibility with Russian needs } \\
\text { (dominant - energy efficiency and } \\
\text { environmental friendliness) } \\
\text { Adaptability and flexibility of the } \\
\text { assessment system } \\
\text { Certification by an independent auditor }\end{array}$ & $\begin{array}{l}\text { Excessive flexibility of the assessment } \\
\text { system } \\
\text { Lack of accounting of the Russian system } \\
\text { of normative-technical documentation }\end{array}$ \\
\hline & $\begin{array}{l}\text { Possibility of certification of buildings in } \\
\text { operation } \\
\text { Accounting for the realities of a specific } \\
\text { project } \\
\text { Great attention to environmental } \\
\text { friendliness }\end{array}$ & $\begin{array}{l}\text { Possibility of lobbying the interests of the } \\
\text { customer } \\
\text { Danger of greenwashing at the stages of } \\
\text { construction and operation of the facility }\end{array}$ \\
\hline \multirow{2}{*}{ 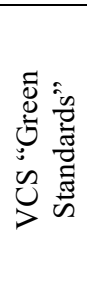 } & $\begin{array}{l}\text { The presence of a criterion for choosing a } \\
\text { building site, as well as the existence of } \\
\text { measures to protect the natural } \\
\text { environment during construction }\end{array}$ & $\begin{array}{l}\text { No assessment during the life cycle } \\
\text { Many poorly formalized expert } \\
\text { assessments }\end{array}$ \\
\hline & $\begin{array}{l}\text { Consideration of country specifics of the } \\
\text { Russian Federation and its NTD }\end{array}$ & $\begin{array}{l}\text { Impossibility of a correct assessment of } \\
\text { economic efficiency } \\
\text { The possibility of lobbying interests due } \\
\text { to the subjectivity of assessments }\end{array}$ \\
\hline \multirow{2}{*}{ 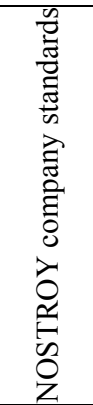 } & $\begin{array}{l}\text { Included in the NOSTROY } \\
\text { standards } \\
\text { There are minimally } \\
\text { requirements }\end{array}$ & $\begin{array}{l}\text { Based on foreign methods } \\
\text { Determinant - energy saving } \\
\text { Lack of an object life cycle assessment } \\
\text { Lack of innovation accounting } \\
\text { No consideration of the specifics of } \\
\text { industrial facilities }\end{array}$ \\
\hline & $\begin{array}{l}\text { Comparability of standards } \\
\text { Ability to determine the minimum } \\
\text { "threshold" level }\end{array}$ & $\begin{array}{l}\text { Difficulty of adaptation to the Russian } \\
\text { NTD system } \\
\text { Insufficient consideration of } \\
\text { environmental friendliness of the } \\
\text { facilities }\end{array}$ \\
\hline
\end{tabular}




\begin{tabular}{|c|c|c|}
\hline \multirow{2}{*}{ 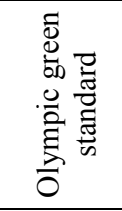 } & Accounting for unique aspects, NTD & $\begin{array}{l}\text { Based on foreign standards } \\
\text { Designed during construction }\end{array}$ \\
\hline & $\begin{array}{l}\text { Assessment of unique structures and } \\
\text { infrastructure facilities }\end{array}$ & $\begin{array}{l}\text { Difficulty of adaptation to the Russian } \\
\text { NTD system } \\
\text { Formal approach to assessment }\end{array}$ \\
\hline \multirow{2}{*}{ 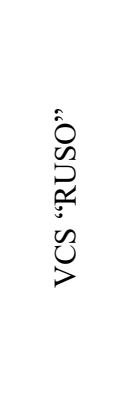 } & $\begin{array}{l}\text { Assessment is performed by the method } \\
\text { of visual, documentary, design, or } \\
\text { instrumental control } \\
\text { Most evaluation criteria have a parametric } \\
\text { value } \\
\text { Compliance with the Russian NTD } \\
\text { system }\end{array}$ & $\begin{array}{l}\text { Taking into account only the Russian } \\
\text { NTD }\end{array}$ \\
\hline & $\begin{array}{l}\text { Sufficient objectivity of assessment } \\
\text { Increased confidence due to verification } \\
\text { of assessments with regard to } \\
\text { international systems }\end{array}$ & $\begin{array}{l}\text { Lack of assessment experience and } \\
\text { reduced confidence }\end{array}$ \\
\hline \multirow[t]{2}{*}{ 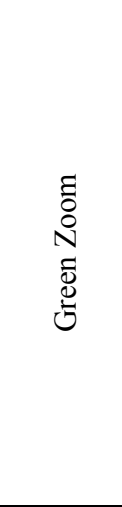 } & $\begin{array}{l}\text { Corresponds to Russian needs (dominant } \\
\text { - energy efficiency and environmental } \\
\text { friendliness) } \\
\text { Based on LEED method with account for } \\
\text { Russian NTD } \\
\text { Accounting for innovation } \\
\text { Contains criteria for selecting a building } \\
\text { site } \\
\text { Postulates the need for building control }\end{array}$ & $\begin{array}{l}\text { Assessment is carried out by a single } \\
\text { operator } \\
\text { Assesses civilian buildings only } \\
\text { Not developed regional specifics } \\
\text { Mainly accounting for the project stage of } \\
\text { life cycle }\end{array}$ \\
\hline & $\begin{array}{l}\text { Accounting for international certification } \\
\text { experience } \\
\text { Support of the object after operation } \\
\text { Compliance with the parameters of PD } \\
\text { The use of renewable energy }\end{array}$ & $\begin{array}{l}\text { Possibility of lobbying interests and } \\
\text { voluntarism in the assessment }\end{array}$ \\
\hline \multirow{2}{*}{ 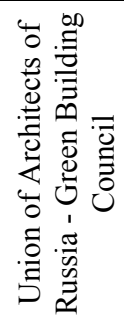 } & $\begin{array}{l}\text { Object life cycle assessment } \\
\text { Typological approach } \\
\text { Accounting for Russian NTD }\end{array}$ & $\begin{array}{l}\text { Evaluates civilian buildings only } \\
\text { Not developed regional specifics }\end{array}$ \\
\hline & $\begin{array}{l}\text { Conformity assessment at the operation } \\
\text { stage } \\
\text { Ability to determine the minimum } \\
\text { "threshold" level of compliance } \\
\text { The use of renewable energy }\end{array}$ & of accounting for \\
\hline
\end{tabular}

Based on the SWOT-analysis of certification systems, we consider the following conclusions to be appropriate.

First, as a result of the analysis of certification systems, a clear pair of vector dominants is distinguished: “energy efficiency - environmental friendliness". Secondly, an important problem in the implementation of any eco-certification system in Russia is the lack of a certification system for building materials. In the presence of a number of certification systems ("Leaf of Life", etc.), there is no obligation to create such databases. Thirdly, most certification systems operate only at the design and construction stages, not taking into account further stages of the facility life cycle, at which the required energy efficiency and environmental performance indicators may be violated (for example, as a result of repair, operation, or during construction of other objects nearby). Fourth, there are at least three global systems of "green" certification, taking into account representative statistical material on implemented projects. Assessment criteria express global requirements and characteristics of sustainable development and eco-efficiency. Almost all the systems 
analyzed by modifying the basic criteria and their weights are adapted to the national characteristics.

Nowadays in Russia, there is no uniform regulatory and methodological framework that forms an objective, integrated approach to the implementation of "green" construction at all stages of the life cycle. However, taking into account the Russian specifics of the real estate market, climatic conditions, institutional system, it is necessary to develop a unified system of environmental certification, taking into account country and regional features. In addition, it is necessary to take into account the innovativeness of "green" construction projects when they are certified in order to correctly calculate the cost, risks, and efficiency.

Based on the analysis of criteria for certification of green building facilities, a theoretical framework for the problems of "green" construction [8-12], available expert opinions, groups of possible innovations in green building are systematized (Table 3). The list of innovations and technologies of "green" construction is not complete, but represents the main examples.

Table 3. Systematization of innovations in "green" construction by the type of innovation.

\begin{tabular}{|c|c|c|c|c|}
\hline 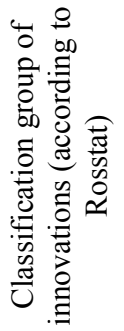 & 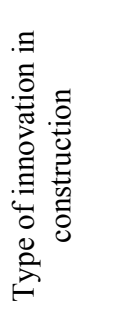 & 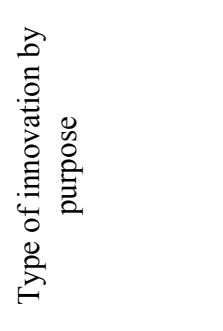 & 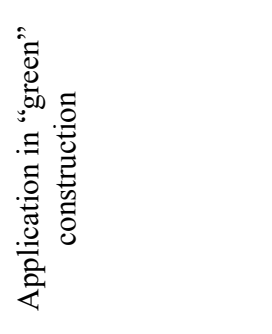 & 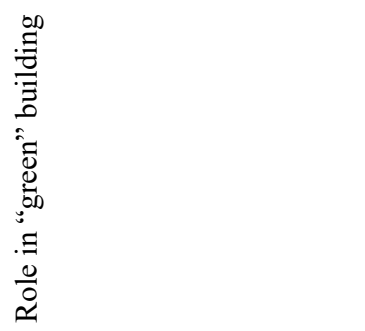 \\
\hline \multirow{6}{*}{ 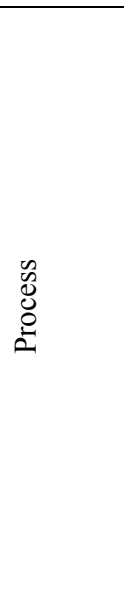 } & \multirow{3}{*}{ 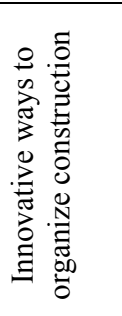 } & $\begin{array}{l}\text { Production } \\
\text { purpose }\end{array}$ & $\begin{array}{l}\text { Energy modeling } \\
\text { projects }\end{array}$ & $\begin{array}{l}\text { Saving of time and increase } \\
\text { of accuracy of an estimation } \\
\text { of design decisions }\end{array}$ \\
\hline & & Custom purpose & $\begin{array}{l}\text { Mathematical } \\
\text { modeling } \\
\text { illumination }\end{array}$ & $\begin{array}{l}\text { Environmental friendliness, } \\
\text { energy efficiency, safety }\end{array}$ \\
\hline & & $\begin{array}{l}\text { Operational } \\
\text { purpose }\end{array}$ & Transport planning & Economical efficiency \\
\hline & \multirow{3}{*}{ 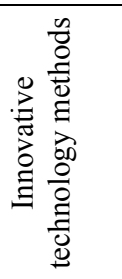 } & $\begin{array}{l}\text { Production } \\
\text { purpose }\end{array}$ & $\begin{array}{l}\text { Construction waste } \\
\text { disposal system }\end{array}$ & $\begin{array}{l}\text { Low waste, environmental } \\
\text { friendliness }\end{array}$ \\
\hline & & Custom purpose & $\begin{array}{l}\text { Building } \\
\text { management } \\
\text { systems }\end{array}$ & $\begin{array}{l}\text { Efficiency, resource saving, } \\
\text { comfort, safety }\end{array}$ \\
\hline & & $\begin{array}{l}\text { Operational } \\
\text { purpose }\end{array}$ & $\begin{array}{l}\text { Pellet heating } \\
\text { system }\end{array}$ & $\begin{array}{l}\text { Energy efficiency, cost } \\
\text { reduction }\end{array}$ \\
\hline \multirow{3}{*}{$\begin{array}{l}\overrightarrow{0} \\
\overrightarrow{0} \\
0 \\
0 \\
0\end{array}$} & \multirow{3}{*}{ 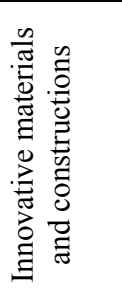 } & $\begin{array}{l}\text { Production } \\
\text { purpose }\end{array}$ & $\begin{array}{l}\text { Recycled materials, } \\
\text { photovoltaic } \\
\text { transducers }\end{array}$ & Resource saving \\
\hline & & Custom purpose & $\begin{array}{l}\text { Eco-building } \\
\text { materials }\end{array}$ & Safety for human health \\
\hline & & $\begin{array}{l}\text { Operational } \\
\text { purpose }\end{array}$ & $\begin{array}{lr}\text { Alternative } & \text { energy } \\
\text { sources, heat- } & \text { heaterials }\end{array}$ & $\begin{array}{l}\text { Economical efficiency, } \\
\text { energy efficiency }\end{array}$ \\
\hline 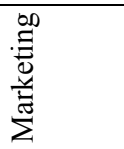 & 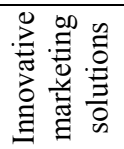 & $\begin{array}{l}\text { Production and } \\
\text { custom purpose }\end{array}$ & $\begin{array}{l}\text { Environmental } \\
\text { certification, pricing }\end{array}$ & $\begin{array}{l}\text { Economic effect, increase in } \\
\text { production and sales }\end{array}$ \\
\hline
\end{tabular}




\begin{tabular}{|c|c|c|c|c|}
\hline 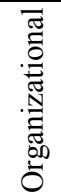 & 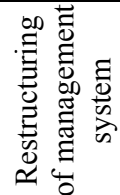 & $\begin{array}{l}\text { Production and } \\
\text { custom purpose }\end{array}$ & $\begin{array}{l}\text { Environmental } \\
\text { management, } \\
\text { certification }\end{array}$ & $\begin{array}{l}\text { Economic effect, increase in } \\
\text { production and sales, } \\
\text { increased competitiveness }\end{array}$ \\
\hline
\end{tabular}

As can be seen from the table, all types of innovations are used in the "green" construction. In addition, the "end-to-end" introduction of innovations at every stage of the life cycle of a "green" building project is very important. However, such an increase in the level of innovation will lead to an increase in the value of objects, which can be negatively assessed at the stages of monitoring design estimates or technological, design, construction audits [9].

One of the most important issues of the effectiveness of introducing innovations, including those that meet the requirements of eco-certification systems, concerns the choice of effect criteria. Today, the most important criterion for the efficiency of real estate construction projects, which are taken as a benchmark in the implementation of procedures for optimizing design decisions in technological, price, and construction audits, is reducing project cost parameters and reallocating funds for other organization projects. When implementing the entire life cycle of a project, the correspondence of actual costs to the project budget is also the most important criterion of efficiency. The efficiency of optimization of design solutions for this criterion is not in doubt, however, in most cases, reduction ofcostsdoes not entail any innovative design or organizational solutions. Based on an empirical analysis of the results of technological and price audits for projects of Russian Railways, we have clusterized the results (Fig. 1).

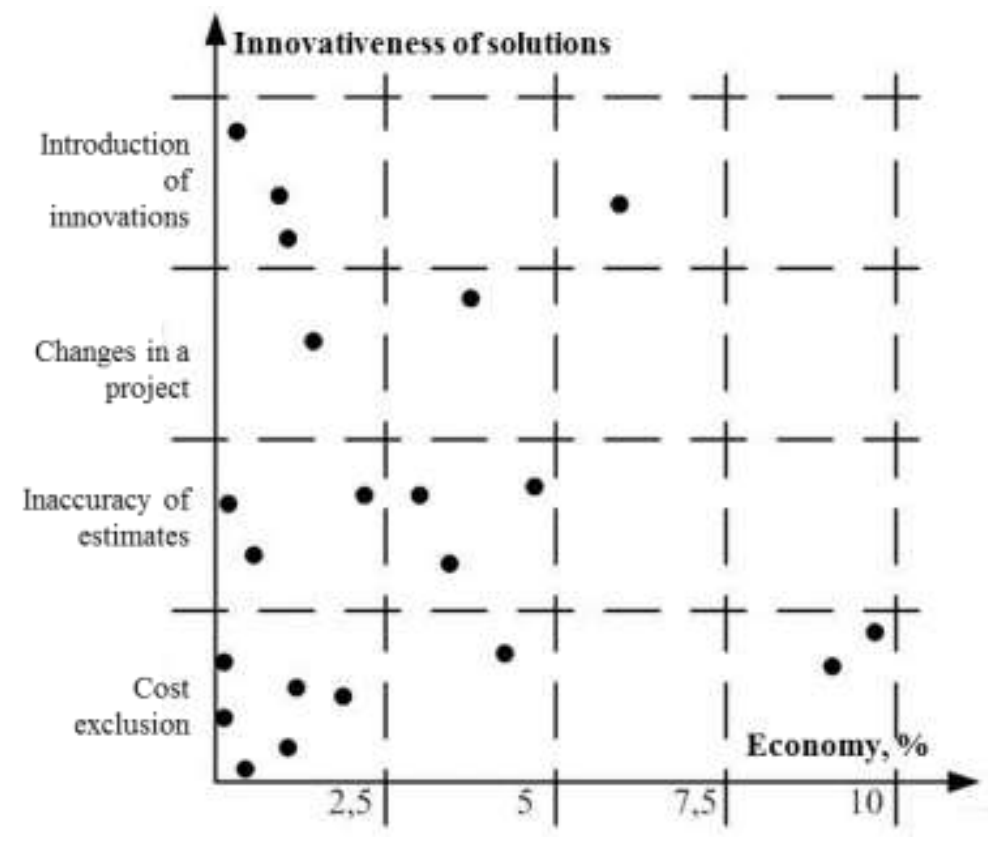

Fig. 1.Clustering the results of audit procedures according to the criteria of efficiency and innovation.

However, based on the goal of enhancing the environmental friendliness of construction, we substantiated the need to change the structure of criteria indicators of the efficiency of auditing investment projects for real estate construction, taking into account 
the intensification of innovation activities and improving environmental friendliness and quality of investment projects and construction products.

\section{Discussions}

The use of any certification system for "green" construction requires compliance with a huge number of regulations, including "green" standards and Eurocodes. The lack of experience and practice of taking into account standards, methods of energy efficiency modeling among domestic specialists negatively affects the development of "green" certification.

The key economic problem in this context is the need to increase capital costs by at least $15 \%$. In this aspect, the necessary transformation is taking into account in the system of design, construction, and technological and price audits of investment and construction projects not so much the criteria of cost minimization as the optimization criteria "priceenvironmental friendliness", "price-innovation". The absence of the requirement of mandatory compliance with "green" standards leads to variability in investor behavior, which is exacerbated by the complex and multi-subjectnature of the construction communication process: the investor, designer, general contractor, contractors, and operating organizations represent various legal entities between which the interaction process is implemented.

Therefore, when introducing environmental certification systems, as well as the construction audit mechanism, during the life cycle of the object, it is necessary to prevent a conflict of interest. It was proposed to take into account the interests of the parties using the methods of the theory of matrix games, binary choice models, and methods of the information approach. It has been proposed to use methods for assessing the quality and objectivity of information in order to form non-manipulative investment distribution mechanisms within the framework of the algorithm for optimizing information flows of the entire complex of the corresponding organizational and economic changes.

\section{Conclusion}

In the context of forming trends in the development of the real estate market, aspects of improving the quality of real estate and reducing current operating costs are becoming relevant, which is the focus of the "green" construction issues.

With the gradual saturation of the real estate market, the demand for "green" buildings will grow due to a number of competitive advantages compared to buildings that do not meet the "green" standards. However, to enhance the "green" construction, it is necessary to implement a complex of interrelated organizational and economic changes, including the development of a unified all-Russian certification system for "green" construction objects that takes into account the specifics of the country and regions, the institutional requirements for compliance with environmental standards, and the modification of design and construction audit criteria for optimization "price-environmental friendliness", "priceinnovation", the intensification of innovation activity in construction and related industries.

\section{References}

1. I.G. Lukmanova, E.V. Nezhnikova, A.A. Aksyonova, Sozdanie sistemy menedzhmenta kachestva, ohranyzdorov'ya, bezopasnostiiekologii v stroitel'nojotrasli (Moskow, 2017) 
2. S.A. Isaev, P.A. Baranov, N.I. Vatin, Y.V. Zhukova, A.G. Sudakov, Technical Physics Letters 40(8), 653-6 (2014)

3. H.M. Gumba, E.A. Prohin, Ekonomika I predprinimatel'stvo 4-1(69), 841-844 (2016)

4. E. Nezhnikova, IOP Conf. Series: Earth and Environmental Science 90 (2017)

5. S. Uvarova, V. Vlasenko, A. Bukreev, L. Myshovskaya, O. Kuzina, E3S Web of Conferences 03022 (2018)

6. P.G. Grabovyj, Servejing: organizaciya, ekspertiza, upravlenie: praktikum $v 3$ chastyah (Moskow, 2016)

7. N.I. Truhina, E.Yu. Okolelova, Nedvizhimost': ekonomika, upravlenie 4, 33-38 (2017)

8. A.N. Larionov, M.Y. Mishlanova, Razvitie ekologo-ekonomicheskoj sistemy «stroitel'stvo - sreda zhiznedeyatel'nosti» (Moskow, 2017)

9. S.S. Uvarova, I.G. Lukmanova, Izvestiya vysshih uchebnyh zavedenij. Tekhnologiya tekstil'noj promyshlennosti 3(369), 29-33 (2017)

10. S.V. Rodionova, Vestnik MGSU 6, 131-139 (2015)

11. I. Ilin, O.V. Kalinina, O. Iliashenko, A. Levina, Procedia Engineering, 165, 1673-1682. (2016) doi: 10.1016/j.proeng.2016.11.909

12. A.R. Bril, O.V. Kalinina, I.V. Ilin, A.S. Dubgorn, O.Y. Iliashenko, Forecasting the turnover growth in the risk management system as management decisions support. Proc. of 2017 20th IEEE Int. Conf. on Soft Computing and Measurements, SCM 2017. Paper number 7970692, 692-693 (2017) DOI: 10.1109/SCM.2017.7970692 